\title{
ゆるみ防止機能を有するハイパーロックナットの開発*
}

（第 1 報, 三次元有限要素法による弾塑性解析）

\author{
西山修二*1, 右田博章*2, 片岡光 ${ }^{* 2}$ \\ 中 崎信 行*3, 村 野 功 史*4
}

\section{Development of Anti-Loosening Performance of Hyper Lock Nut (1st Report, Elasto-Plastic Analysis by Three-dimensional Finite Element Method)}

\author{
Shuji NISHIYAMA*5 ${ }^{* 5}$ Hiroaki MIGITA, Mitumasa KATAOKA, \\ Nobuyuki NAKASAKI and Kohshi MURANO

\footnotetext{
${ }^{* 5}$ Department of Systems Engineering for Sports, Faculty of Computer Science and System Engineering, Okayama Prefectural University, 111 Kuboki, Soja-shi, Okayama, 719-1197 Japan
}

\begin{abstract}
Bolted joints are widely used in mechanical structures since the disassembly for maintenance is easy without high cost. However, vibration induced loosing due to dynamic loading has been unsolved subject for a long time. We have developed a new type of nut named 'hyper lock nut (HLN), which realizes anti-loosening performance without complicated tightening process and tool. In this study, we have investigated the mechanisms of bolted joint with HLN, and tightening behavior are analyzed by mean of three-dimensional finite element method. Results are compared with the experimental results for HLN. Good qualitative agreement is observed between analytical results and experiments with respect to displacement, tightening force and tightening torque. We found some new aspects and superior points for bolted-joint with HLN than that of standard nuts. It is found that tightening torque of HLN is higher than that of standard. It is also found that the antiloosening performance can be realized by the thread contact force at the slit region and angular facing on bearing surface. Moreover, by mean of tensile and fatigue experiments, it is concluded that HLN involves sufficient strength in practical use.
\end{abstract}

Key Words : Finite Element Method, Machine Element, Bolted Joint, Fracture Mechanics, ElastoPlastic Analysis

\section{1. 緒}

機械や構造物を組み立てる際に使用される結合法の 一つにボルト締結がある. 取り付けや取り外しの容易 さ，価格の安さなどの面から幅広く使用されている(1). しかし，ボルト締結体に衝撃や振動, あるいは熱負荷 などの動的な外力が作用すると，ナットはしばしば戻 り回転を開始し, 締結力を失い, 締結部はその機能を はたさなくなる(2).

現在に至っても産業界において，ボルト・ナットの ゆるみに起因する事故が多発している. ボルト・ナッ トによる締結体のゆるみの問題は工学分野において解 決すべき重要な課題の一つである(3).

ナットがゆるむ現象は，ボルトとナットの両座面間

* 原稿受付 2006 年 4 月 6 日.

*1 正員, 岡山県立大学情報工学部 (画 719-1197 総社市䆶木 111).

*2 (株) エコーワールド (昰 733-0003 広島市西区三篠町 6-9).

*3 エヌ・テクニカ (㞼737-0046 呉市中通 1-5-26-603).

*4 正員, 広島市産業振與センター(画 730-0052 広島市中区千 田町 3-8-24).

E-mail : nisiyama@ss.oka-pu.ac.jp
の距離が締結初期の距離より変化してボルト軸の弾性 力が減少することを示す．締結間距離の弾性力の減少 は, 被締結物が熱収縮などで収縮する場合やナットが 回転して締結間距離が大きくなる場合などに生じる.

ボルト締結体のゆるみの問題を解決する一つの方法 として，著者らは，新しいゆるみ止め機構を備えた八 イパーロックナット (Hyper Lock Nut:以下 HLN 之略記 する)を開発した(4)(5). HLNは，六角ナットにスリット とナット座面に傾斜面が加工してある. ゆるみ止めね じ部品として HLNを選択する際の明確な指標を提供 するためには，そのメカ二ズムを解明し，かつ強度や 力学的特性に及ぼす影響の評価が必要である(6)(7).

そこで, 本研究では, 三次元有限要素法を適用して, 弾塑性解析をおこないHLNを使用したボルト締結体 の性能を解析的に評価する，評価する性能として，締 付時のトルク管理に不可欠な締付け回転角と締付け軸 
力の関係, 締付け回転角之締付けトルクの関係, 締付 け軸力と締付けトルクの関係およびねじ各部の強度解 析を行う.

\section{HLNの仕様}

図 1 は, HLNを示す. 図 1(a)は, HLN(M16)の実物 写真を示す. 図 1(b)は, HLNの正面図および側面図 を示す．HLNは，ゆるみ止め性能を有するナットで ある. HLNは六角ナットに図のような平行なスリッ トと傾斜座面を加工して作成する，スリットの位置は ナット座面とは反対側のナット上面に近い位置に設け られている. さらに, ナット座面は $1^{\circ}$ の傾斜面に加 エしてある.

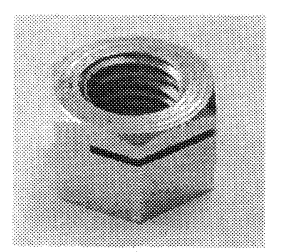

(a) Photograph of Hyper Lock Nut
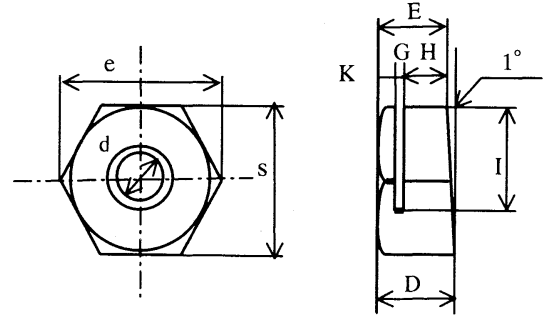

(b) Schematics of top and side views

Fig.1 Hyper Lock Nut (HLN)

解析に用いる HLNは M16 とし, 各部の寸法は, $\mathrm{e}=27.7 \mathrm{~mm}, \mathrm{~s}=24.0 \mathrm{~mm}, \mathrm{P}=2.0 \mathrm{~mm}, \mathrm{~W}=36.0 \mathrm{~g}, \mathrm{D}=16.0 \mathrm{~mm}$, $\mathrm{G}=1.2 \mathrm{~mm}, \mathrm{H}=10.0 \mathrm{~mm}, \mathrm{I}=18.7 \mathrm{~mm}, \mathrm{E}=15.6 \mathrm{~mm}, \mathrm{~K}=4.4 \mathrm{~mm}$ で ある. HLNは, M10から M42まで対応している. ス リット幅(G)は M10で $0.8 \mathrm{~mm}, \mathrm{M} 12$ で $1.0 \mathrm{~mm}, \mathrm{M} 16$, $\mathrm{M} 20$ で $1.2 \mathrm{~mm}, \mathrm{M} 24$ で $1.5 \mathrm{~mm}, \mathrm{M} 30 \sim 42$ で $2.0 \mathrm{~mm}$ である. HLNは, 傾斜座面とスリットにより, はめあいねじ 部に大きな接触力を発生させ, ゆるみ防止効果を発揮 することが期待される.

\section{3.解析手法}

3-1 H L N のモデル化および境界条件 図 2 に HLN を使用したボルト締結体の解析モデルを示す. 図 2 は, ねじのつる巻き線を忠実にモデル化した三次元有限要素 モデルである.
ボルト締結体の力学特性に巻き線が及ぼす影響を示す例 として, ねじを切った棒が単純な引張荷重を受けると, 軸方向の伸びだけでなく円周方向にわずかに回転するこ とが報告されている®、ねじのつるまき線は，ねじの本 質的な幾何学形状であると同時に強度評価を複雑力つ難 解にする. しかし, 本研究では, 高精度かつモデルを忠 実に再現するために, ねじのつる巻き線まで考慮したモ デル化を行う．モデル化にあたり，ボルトの遊びねじ部 は 5 山, グリップ長さを $80 \mathrm{~mm}$, 被締結物は剛体と仮定 する. ねじ寸法は $6 \mathrm{H} / 6 \mathrm{~g}$ の公差域内の呼び径 M16 のメ 一トル並目ねじとする. 要素は一次元四面体要素を用い, ねじ面の接触部およびナット座面の部分は締付けトルク を精度よく解析するために要素を密に分割する. ナット 座面, ねじ面，および被締結物接触面には接触面要素を 設定する.

解析ソフトとしてADINA 8.0 を使用する. 解析は ボルトを回転する弾塑性締付けをモデル化し実施する. HLN の特徵であるスリットや傾斜座面が締付けトル クなどのねじ特性に及ぼす影響を検討するために, HLN(model-1), 傾斜座面付きナット(HLNのスリット

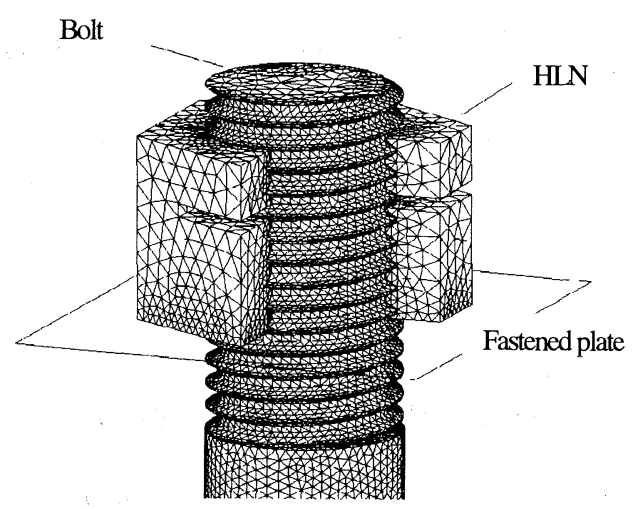

Fig. 2 Three-dimensional finite element model for $\mathrm{HLN}$ ( $1 / 4$ of nut is visually removed in this figure)

を除いたモデル：model-2), スリット付きナット(HLN の傾斜座面を除いたモデル : model-3), JIS 標準ナット (model-4)の 4種類のモデルについて検討する. 四つの モデルの概略図を図3に示す.

解析に用いた材料物性值として, ボルト・ナットの 縦弾性係数は $200 \mathrm{GPa}$ とする. また, ボルト・ナット のポアソン比は 0.3 とする. ボルトの強度区分は 10.9 , ナットを 8 とする. 初期降伏応力はボルトを $790 \mathrm{MPa}$, ナットを $790 \mathrm{MPa}$ とする. 塑性則は線形硬化弾塑性体 とし, 塑性の接線係数はボルト・ナット共に $2700 \mathrm{MPa}$ とする. 

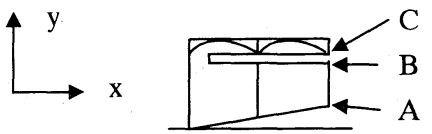

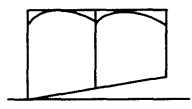

Model-2
Model-1(HLN)

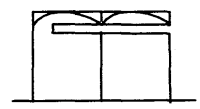

Medel-3

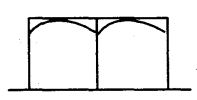

Model-4(JS)
Fig.3 Physical models for analysis

解析は材料非線形および幾何学的非線形を考慮した弾 塑性解析とする. 接触面における摩擦係数は 0.15 と し, 締付け過程において摩擦係数は一定と仮定する.

3.2 HLN の解析条件 HLNの三次元有限要素モデ ルの節点数は 18014 , また要素数は 71669 である. 解 析は締付け回転角を $0^{\circ}$ からスタートし， $0.1^{\circ}$ 毎に 計算を進めていき, $150^{\circ}$ くらいまで進める. 解析結 果は $1^{\circ}$ 毎に出力する. 解析に用いた CPUは Pentium 4, $2.4 \mathrm{GHz}$ のコンピュータを使用する. 1 Runの計算 時間は約 40 時間である.

\section{4.解析結果}

4.1 解析結果の妥当性 図 4 は, 解析結果の妥当 性を検証するために図 3 に示す Model-1(HLN)の A，B， $\mathrm{C}$ 点の $\mathrm{x}, \mathrm{y}$ 方向の変位量の解析結果を示す. 各点の $\mathrm{x}$ および $\mathrm{y}$ 方向の変位量は, 締付け回転角の増加とと もに, 徐々に増加する. 締付け回転角が $50^{\circ}$ 近傍に 達すると $\mathrm{A}, \mathrm{B}, \mathrm{C}$ 点の $\mathrm{x}, \mathrm{y}$ 方向の变位量はピークに 達する．その後は A, B, C 点の y 方向変位は一定值 $(0.4 \mathrm{~mm})$ を維持する.

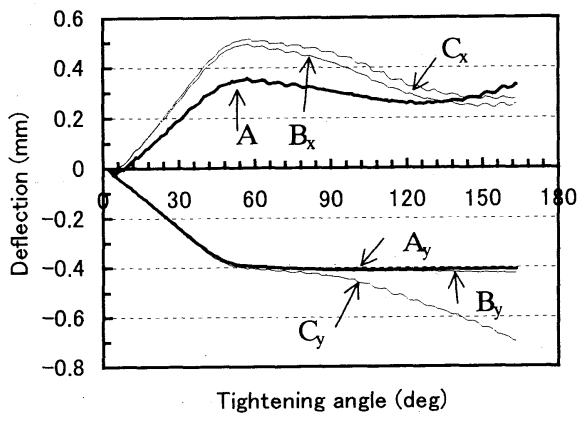

Fig.4 Effect of deflection on tightening angle

図3において, Dから $\mathrm{E}$ 差し引いた值が $0.4 \mathrm{~mm}$ とな りこの寸法に一致する. しかし, $\mathrm{C}$ 点の $\mathrm{y}$ 方向変位は
さらに増加していく．締付け回転角が $50^{\circ}$ 近傍にお いて，HINの傾斜座面が完全に密着し，A， B 点の y 方向変位はこれ以上变位しなくなる. しかし， C点の y方向変位はスリット幅の減少によりさらに変位する.

一方，A，B，C点の $\mathrm{x}$ 方向の変位は，締付け回転 が増加すると，傾斜座面が着座するまでは一様に増加 し, 着座後は, 減少し, 一定值に落ち着く. 以上の検 討は, ナット各部の変位量に着目した検討であるが, 解析結果の妥当性を示すものである.

次に, 図 5から図 7は, Model-1(HLN)の解析結果の 妥当性を検証するために解析結果と実測結果の比較を 示す. 実測試験にあたっては, ナットの締付け試験装 置を開発した. 各種ナットの締付け回転角, 締付け軸 力および締付けトルクの関係が実測できる. 開発した 装置は，駆動用モ一夕，変速機，角度検出センサ，卜 ルク変換器, ワッシャ一型ロードセル, センサインタ ーフェース, およびコンピュータから構成されている.

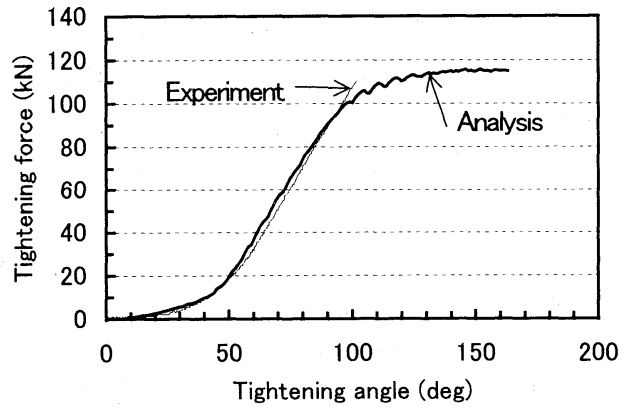

Fig.5 Comparison of the numerical results with experimental results of the relationships between tightening angle and tightening force

図 5 は, 締付け回転角之締付け軸力の解析結果と実 測結果の比較を示す. 図の横軸は締付け回転角, 縦軸 は締付け軸力を示す. 解析結果においては, 締付け回 転角が $9^{\circ}$ 近傍から締付け軸力が立ち上がる. $43^{\circ}$ 近 傍まではゆるやかに増加する．この区間の増加率は $0.29 \mathrm{kN} / \mathrm{deg}$ である. $50^{\circ}$ から $100^{\circ}$ の間は, $1.8 \mathrm{kN} / \mathrm{deg}$ の増加率で变化する. $50^{\circ}$ でナットの傾斜座面が被 締結物に完全に密着し, 軸力の増加率が高くなる. 締 付け回転角が $100^{\circ}$ を越えると, ボルト・ナットが塑 性域に入り, 回転角の増加とともに変形が発生し, 締 付け軸力の増加率が緩やかになる. 実測結果において も同様な傾向を示す. 両者の特性および值はよく一致 している.

図6は, 締付け回転角之締付けトルクの解析結果と 実測結果の比較を示す. 図の横軸は締付け回転角, 縦 


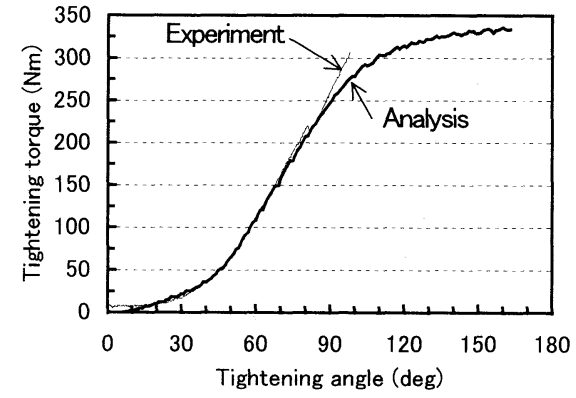

Fig.6 Comparison of the numerical results with experimental results of the relationships between tightening angle and tightening torque

軸は締付けトルクを示す．締付け角度が $9^{\circ}$ 近傍から 締付けトルクが立ち上がる. $43^{\circ}$ 近傍まではゆるや かに増加する.この区間の増加率は $1.0 \mathrm{Nm} / \mathrm{deg}$ である. $50^{\circ}$ で傾斜座面が完全に密着し, 軸力が発生する.

$50^{\circ}$ から $100^{\circ}$ の間は, $4.55 \mathrm{Nm} / \mathrm{deg}$ の増加率で締付け トルクが増加する. 締付け回転角が 100 。 を越えると, ボルト・ナットが塑性域に入り, 回転角の増加ととも に変形が発生し, トルクの増加が緩やかになる. 実測 結果も同様な傾向を示し，両者の特性および值はよく 一致している.

図 7は, 締付け軸力と締付けトルクの関係について, 解析結果と実測結果の比較を示す. 締付け軸力が全て の帯域において, 両者の值はよく一致している. 解析 結果において, 締付けトルクの増加率は $2.90 \mathrm{Nm} / \mathrm{kN}$ である. 以上より, 本研究のボルト・ナットのモデル 化および解析結果は妥当性があるものと考えられる. 解析結果の信頼性を示すものである.

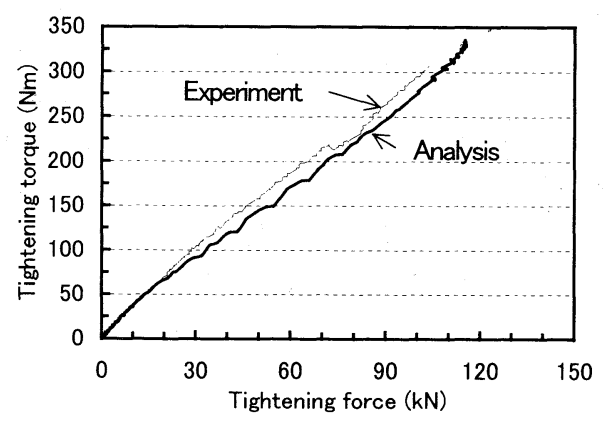

Fig.7 Comparison of the numerical results with experimental results of the relationships between tightening force and tightening torque

4-2 回転角之軸力の関係 図 8は, Model-1 から Model-4 に対して, 締付け回転角之締付け軸力の解析 結果を示す，図において，横軸は締付け回転角，縦軸
は締付け軸力を示す. Model-3,4 は締付け回転角が $7^{\circ}$ 近傍から締付け軸力が一様に増加する. Model-4は締 付け回転角が $67^{\circ}$ 近傍まで, Model-3 3 は $47^{\circ}$ 近傍ま では締付け軸力は一様に増加する傾向を示す．この間 の増加率は $2.05 \mathrm{kN} / \mathrm{deg}$ である.

一方, Model-1,2 は, 締付け回転角が $11^{\circ}$ 近傍までは 締付け軸力は発生しない. これは, ナットの座面に 1 。の傾斜面がつけてあることによるものと思われ る. ボルトが回転して締付け回転角が $12^{\circ}$ 近傍から $47^{\circ}$ 近傍までは, ゆるやかではあるが, 締付け軸力 が発生する.この区間の増加率は $0.25 \mathrm{kN} / \mathrm{deg}$ である. 回転角が $50^{\circ}$ 以上になると勾配が急に大きくなる. これは,Model-1, Model-2の傾斜座面が, 締付け回転角 が $50^{\circ}$ に達すると, ナットの座面が完全に被締結物 に着座することによるものと思われる.

Model-1 は締付け回転角が $47^{\circ}$ 近傍から $84^{\circ}$ 近傍 の間, また Model-2 は締付け回転角が $47^{\circ}$ 近傍から $100^{\circ}$ 近傍まで, 軸力の増加率は, $1.95 \mathrm{kN} / \mathrm{deg}$ となる. 両モデルともに，それ以降の締付け回転角では増加率 はゆるやかになる. ボルト・ナットが塑性域に達した ものと思われる. また, Model-1 と Model-4を比較す ると, Model-4は締付け軸力が $120 \mathrm{kN}$ を超えると増加 率が小さくなる. Model-1 では, 締付け軸力が $80 \mathrm{kN}$ を超えるくらいから増加率が小さくなる. 勾配が小さ くなる点の締付け軸力を比較すると, Model-4よりも

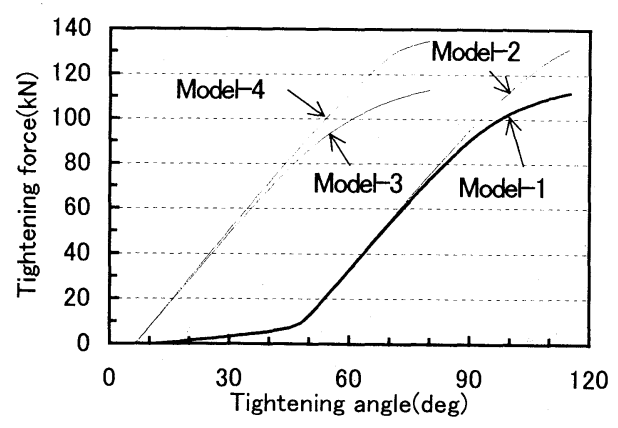

Fig.8 Relationships between tightening angle and tightening force

Model-1 の方が $40 \mathrm{kN}$ 程度小さくなっている.これは, Model-1 は傾斜座面を有することにより, 被締結物に 着座することによりボルト・ナットが変形し, 低い 軸力で塑性変形が発生しているものと思われる.

4-3 回転角と締付けトルクの関係 図 9 は, Model-1 の解析結果を示す. 横軸は締付け回転角, 縦軸は締付 けトルクを示す. 図で $\mathrm{T}_{1}$ は, 締付けトルク, $\mathrm{T}_{2}$ は座 面トルク， $\mathrm{T}_{3}$ はねじ面トルクとリード角トルクを示す. $\mathrm{T}_{1}$ は $\mathrm{T}_{2}$ と $\mathrm{T}_{3}$ の和となる. 


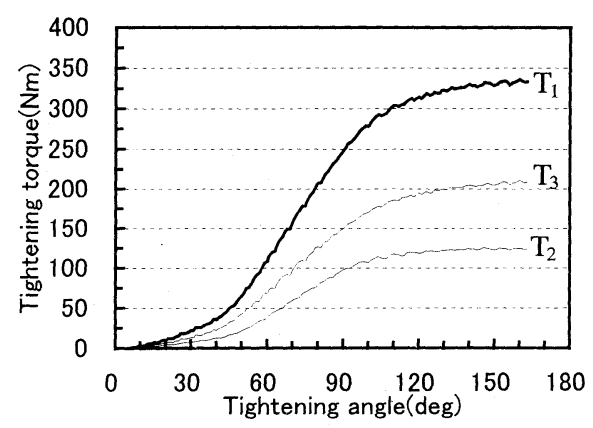

Fig.9 Relationships between tightening angle and tightening torque

Model-1 は回転角 $11^{\circ}$ を過ぎたくらいからトルクが発 生する.これはナットに傾斜座面が付いているためで ある.

図 10は, Model-1 から Model-4の締付け回転角之締 付けトルクの関係を示す. 図において，横軸はナット の回転角，縦軸はボルト締結体の締付けトルクを示す. Model-4は, 締付け回転角が $7^{\circ}$ 近傍から締付けトル クが一様に増加する. 締付け回転角が $67^{\circ}$ 近傍まで は締付けトルクは一様に増加する傾向を示す．この区 間の増加率は $5.20 \mathrm{Nm} / \mathrm{deg}$ である. Model-3 も締付け回 転角が $46^{\circ}$ 近傍までは增加率が $5.20 \mathrm{Nm} / \mathrm{deg}$ であるが それ以降は増加率が緩やかになる. 一方, Model-1 と Model-2は,締付け回転角が $13^{\circ}$ 近傍までは締付けト ルクは発生しない，これは, ナットの座面に $1^{\circ}$ の 傾斜面がつけてあることによるものと思われる.

締付け回転角が $13^{\circ}$ をすぎるくらいから $48^{\circ}$ 近傍ま では，ゆるやかではあるが，締付けトルクが発生する． この区間の增加率は $0.914 \mathrm{Nm} / \mathrm{deg}$ である. 締付け回転 角が $50^{\circ}$ 以上になると勾配が急に大きくなる.これ は, Model-1 の傾斜座面が, 締付け回転角が $50^{\circ}$ 近傍 に達すると, ナットの座面が完全に被締結物に着座す ることによるものと思われる. Model-1 $183^{\circ}$ 近傍, Model-2 は $100^{\circ}$ 近傍までは直線的に増加し, 増加率 は $4.65 \mathrm{Nm} / \mathrm{deg}$ である. また, Model-4 と Model-1 を比 較すると, Model-4は締付けトルクが $300 \mathrm{Nm}$ を超え ると増加率が小さくなる.

Model-1 では, 締付けトルクが $250 \mathrm{Nm}$ を超えるくら いから増加率が小さくなる．勾配が小さくなる点の締 付けトルクを比較すると, Model-4よりも Model-1の方 が 50 Nm 程度小さくなっている.これは, Model-1 は傾 斜座面を有することにより, ナットが被締結物に着座 することによりボルトに曲げモーメントが発生し，塑 性変形が発生しているものと思われる.

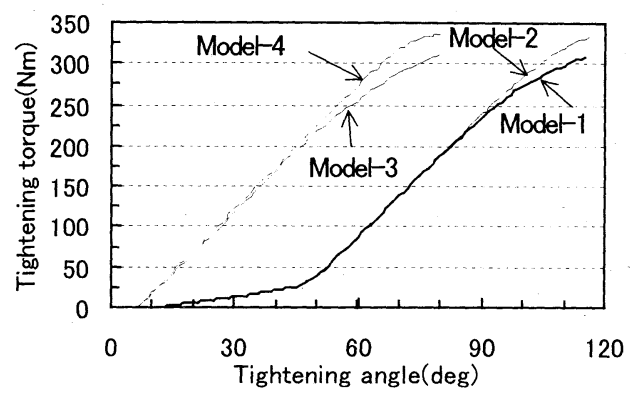

Fig.10 Relationships between tightening angle and tightening torque

4-4 軸力と締付けトルクの関係 図 11 から 14 は締 付け軸力と締付けトルクに関する解析結果を示す. 図 において, 横軸は締付け軸力, 縦軸は締付けトルクを それぞれ示す.

図 11 は, Model-3 と Model-4 の解析結果を示す. 締 付け軸力が $80 \mathrm{kN}$ を過ぎるくらいから, 締付けトルク は Model-4 より大きくなる傾向を示す. 締付け軸力が 大きくなると, スリットの影響が表れるものと考えら れる. HLN のスリットは締付け軸力が大きくなると 締付けトルクを大きくすることに寄与する.

締付け軸力が $113 \mathrm{kN}$ において, 締付けトルクは Model-3 では 311Nm，Model-4 では 278 Nm である. 締 付けトルクは, 締付け軸力が最大值の $113 \mathrm{kN}$ におい て, Model-3が Model-4より $11.8 \%$ 大きい.

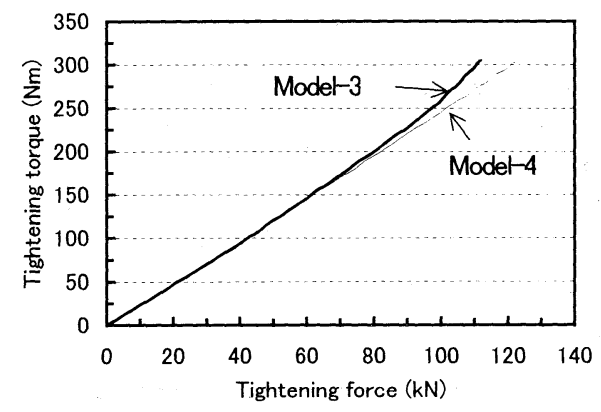

Fig.11 Comparison of model-3 with model-4 of the relationships between tightening force and tightening torque

図 12は, Model-2 と Model-4についての解析結果で ある. 傾斜座面を有するナットは締付け軸力が全ての 帯域において，締付けトルクが 5〜9 Nm, Model-4よ り大きい傾向を示す.

図 13 は, Model-1 と Model-4についての解析結果で ある. 締付け軸力が全ての帯域において, 締付けトル 
クが Model-4より大きい傾向を示す．特に締付け軸力 が大きい帯域では締付けトルクが大きくなる．締付け 軸力が大きくなると, スリットの効果がさらに加わる ものと思われる.

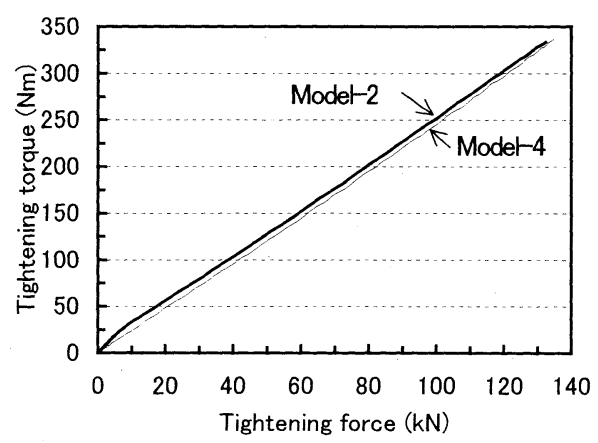

Fig.12 Comparison of model-2 with model- 4 of the relationships between tightening force and tightening torque

例えば, 締付け軸力が $60 \mathrm{kN}$ において, 締付けトル クは Model-1 では 157 Nm，Model-4では 147 Nm である.

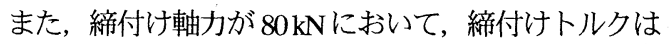
Model-1 では $207 \mathrm{Nm}$, Model-4では $195 \mathrm{Nm}$ である. 締 付け軸力が $100 \mathrm{kN}$ では, 締付けトルクは Model-1 では $263 \mathrm{Nm}$, Model-4 では $244 \mathrm{Nm}$ である. 締付け軸力が $112 \mathrm{kN}$ において, 締付けトルクは Model-1 では 308 Nm, Model-4では 274 Nm である. Model-1 は締付けトルク が 10〜34 Nm 程度大きい特性を有している.

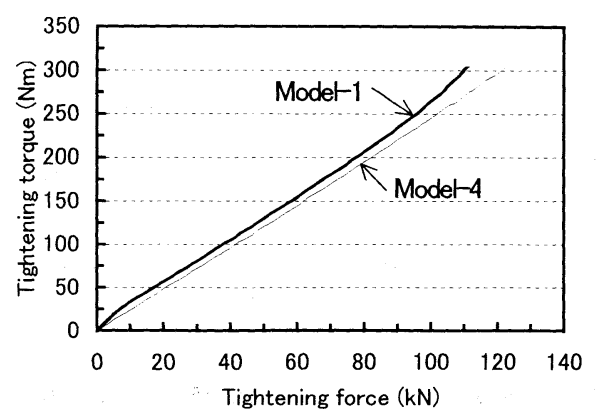

Fig.13 Comparison of model- 1 with model-4 of the relationships between tightening force and tightening torque

Model-3 と Model-4は, 締付け軸力が全ての帯域にお いて同程度の勾配を有する特性を示す。一方, Model1 と Model-2 は締付け開始から締付けトルクが $25 \mathrm{Nm}$ 程度, 前者よりも大きくなっている. これは, 傾斜 座面を有するナットに共通しており, 図9における 締付け回転角が $40^{\circ}$ における締付けトルクが $25 \mathrm{Nm}$
と值が一致している. また, 締付け軸力が $60 \mathrm{kN}$ 以上 において, Model-1 と Model-3 は締付けトルクが徐々に 増大する傾向を示す.これは, ナットにスリットが 入っているモデルに共通した特徴である. 解析結果 において, 軸力の上限值が存在した理由は有限要素モ デルの局所的部分のメッシュが大きく変形し, 計算 が収束しなくなったことによるものと思われる.

4.5 ボル卜軸心とスリ以卜幅の変位 締付け回転角が 増していくと, HLNの傾斜座面とスリットの影響に よりボルトに曲げモーメントが発生し, ボルト軸心と スリット幅が変位する. ボルトの軸心に発生する曲げ モーメントは次のように求めることができる. ナット 座面に傾斜角 $\phi$ がある場合, ボルトには軸力と同時に 次式で表される曲げモーメント $M_{\mathrm{b}}$ が作用する(9).

$$
M_{b}=\int_{r_{h}}^{r_{w} 2 \pi} \int_{0}^{2 \pi} p r^{2} \cos \theta d \theta d r
$$

ここで, $r_{\mathrm{h}}, r_{\mathrm{w}}$ は各々ボルト穴の半径および座面の 半径である. また, $p$ は面圧を示す.

ボルト軸に生じる $M_{\mathrm{b}}$ による曲げ応力は追加応力と なり，その最大值 $\sigma_{b}$ はボル卜軸直径を $d$ とすれば次 式で表される.

$$
\sigma_{b}=\frac{32 M_{b}}{\pi d^{3}}
$$

ボルトの強度を考慮する場合, この $\sigma_{\mathrm{b}}$ を検討してお く必要がある. 一方, はりの理論より, ボルトの曲げ の半径を $\rho$, 曲け剛性を $E I$ とすると,

$1 / \rho=M_{b} / E I$ が成り立つので, $\phi=l / \rho=l M_{b} / E I$ が成立する. 従って曲げモーメント $M_{b}$ は次式となる.

$$
M_{b}=\frac{\phi}{l} E I=\frac{\pi d^{4} E}{64 l} \phi
$$

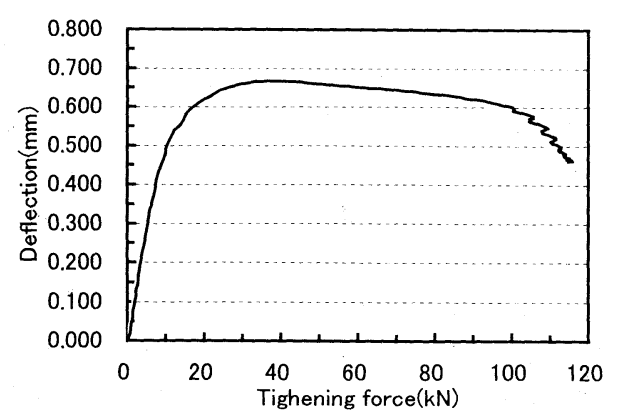

Fig 14 Horizontal deflection of axis of bolt

図 14は,HLNのボルト軸心の変位量に関する解析 結果を示す. 横軸は軸力, 縦軸はボルト軸心の変位量 をそれぞれ示す. ボルト軸力の増加とともに，ボルト 
軸心は一様に変位し, 最大変位が $0.65 \mathrm{~mm}$ くらいに達 する. その後は, 軸力の増加とともに，この変位を維 持し, 軸力が $98 \mathrm{kN}$ くらいから変位がもどり, $118 \mathrm{kN}$ くらいで $0.45 \mathrm{~mm}$ くらいまで回復する. このように軸 力が増加すると, ボル卜軸心の変位がもどる現象は, 軸力が増加すると，スリット幅が変形し，ボルト変位 を減少させているものと考元れる. 図 14 において, 締付け軸力が $7.3 \mathrm{kN}$ までは, 線形域であり, 締付け軸 力とたわみは直線的に变位している. 締付け軸力を $F_{b} \mathrm{kN}$ ，ボルト軸心のたわみ量を $\Delta \mathrm{mm}$ ，ばね定数を $k$ $\mathrm{kN} / \mathrm{mm}$ とおくと，次式が成立する.

$$
\Delta=\frac{1}{k} F_{b} \quad\left(0 \leq F_{b} \leq 7.3\right)
$$

解析結果より, ばね定数 $k$ は $18.25 \mathrm{kN} / \mathrm{mm}$ となる.

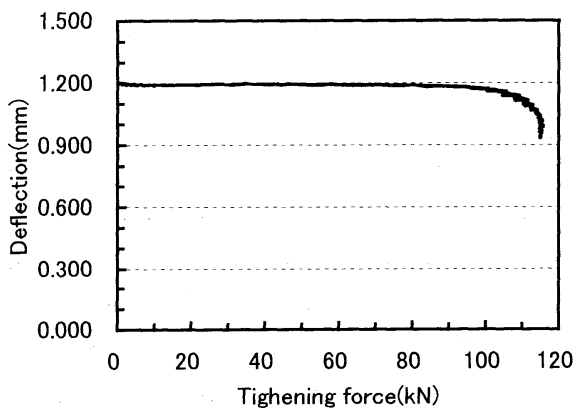

Fig. 15 Vertical deflection of space of slit

図 15 は, HLNのスリット幅の変位量の解析結果を 示す．横軸は締付け軸力，縦軸はスリット幅の変位量 をそれぞれ示す．締付け軸力の増加とともに，スリッ 卜幅は変形することなく $78 \mathrm{kN}$ くらいまで $1.2 \mathrm{~mm}$ の寸 法を維持する. その後は微少ではあるが, 軸力の増加 とともに，幅が多少狭くなる. $118 \mathrm{kN}$ くらいで，スリ ット幅は $0.9 \mathrm{~mm}$ くらに変位する. スリット幅が約 25\%減少し, ナットが変形することにより, ボルトに 作用する曲げモ一メントを多少開放し，同時にねじの 締付けトルクの増加に作用しているものと考えられる.

\section{5. 考察}

ボルトとナットはその構造にゆるみ防止構造も持つ ている. ボルトもナットも締結座面と，おねじとめね じの接合面との二つの面がゆるみ防止構造である.ゆ るみ防止能力は二つの面の摩擦力と摩擦中心の半径と の積である. 座面の摩擦力は軸力と摩擦係数の積であ り，ねじ面の摩擦力は軸力のねじ面垂直分力とねじ面
摩擦係数との積である. 従って, 摩擦係数の大きいボ ルト・ナットや座面半径の大きいボルト・ナットはゆ るみにくい. HLNの傾斜座面およびスリットのゆる み止め機構について考察する.

5・1 HLN の傾斜座面によるゆるみ止め機構 HLN の傾斜座面はねじ山の嵌合がおねじとめねじのフラン ク面での接合だけでなく，おねじ山頂部とめねじ谷底 の接合をももたらす特徵がある. HLN とボルトの締 結初期はナットの回転によって傾斜座面の一部が着座 すると, ボルト軸力が生じ, ナットの回転角の増加に 比例して軸力も増加すると共に着座面積が増加する. この時, 傾斜座面が密着する課程で座面傾斜角がある ために HLN は回転中心線がボルトの中心線から变位 しながら回転し，かつボルトを曲げる．HLNではナ ット中心が偏心してくるので, 傾斜側のお齐じ山頂と めねじ谷が噛合いながら，フランク面が接合している. この現象をトルクの值で考えると, HINのフランク 面接触での摩擦力は JIS 標準ナットでのフランク面の 摩擦力にほぼ等しいが, これに加えて, おねじの半周 側において，おねじ山頂での接触はおねじのねじ山が 楔の形でめねじの谷に食い込むので, 山頂の楔接合の 摩擦力とおねじ半径の積としてのトルクが発生する. このため傾斜座面を有するナットは IS 標準ナットよ りも高いトルクをもたらす. 傾斜座面が全面密着した 後も, 軸力の増加によりボルトの傾きは増加するので 楔接合は強くなる，傾斜座面は，ねじ山の干渉を増し， 摩擦力を増加させる機能を有する.

\subsection{HLNのスリットによるゆるみ止め機構 スリッ} トの機能はスリットが狭小になるとき, めねじの総合 ねじピッチが崩れてくることにより，正常なフランク 面接合のみならず, 背面での接合が生じる事である. ナットの各ねじ山に生じる軸力の負担は座面から近い ねじ山が大きく，ナット高さ方向に移るほど軽減する. スリットより上側のナットねじ山が負担する軸力で, スリットの幅は弾性的に狭小に変位する. 傾斜座面が あるのでナットの中心線はスリット側に变位するから， おねじとめねじの嵌合はスリット側で揳形に食い込み， スリットの反対側ではフランク面のおねじとめねじ間 の隙間が増加する．この時にスリットが狭小になれば 背面側フランク面のおねじとめねじの隙間が減少し, 更に狭小になればスリットの上のめねじ山はボルトお ねじの上面と接触し，お対じ山を挟みつける事になる. この挟みつけ力による摩擦力がトルクの増加になる.

5.3 HLNのゆるみ止め効果 同じ軸力では, 締付 けトルクが大きい方がゆるみ防止効果は大きいものと 考えられる. ボル卜軸力が $20 \mathrm{kN}$ 以下においても, 締 
付け軸力が発生してから HLNは JIS 標準ナットに比 較して，締付け効果が大きい特性を有している. ナッ トの傾斜座面は締付け軸力が発生し始めると締付けト ルクを大きくする効果がある. さらに，スリットは 締付け軸力が $60 \mathrm{kN}$ 以上で締付けトルクを大きくする

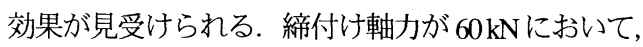
締付けトルクはJS標準ナットより $6.8 \%$ 大きい.さら に, 軸力が増加して $80 \mathrm{kN}$ では $6.2 \%, 100 \mathrm{kN}$ では $7.8 \%, 112 \mathrm{kN}$ では $12.4 \%$ 締付けトルクが大きい特性を 有する.

\section{6. 結 言}

本研究により得られた結果をまとめると次のとおり である.

(1)ハイパーロックナットは締付け回転角が $11^{\circ}$ 近傍 までは, 締付けトルクが発生しない. $12^{\circ}$ 近傍を過 ぎたくらいから徐々に締付けトルクが発生し, $50^{\circ}$ 近傍まで同じ勾配で増加する. $50^{\circ}$ を過ぎたくらい から, JIS 標準ナットと同様に急激に増加する特性を 示す.

(2)軸力が低い領域では, 座面の傾斜面の影響が大き い. 締付け軸力が $10 \mathrm{kN}$ では, ハイパーロックナッ トおよび座面付きナットは締付けトルクが $10 \mathrm{Nm}$ 程 度大きい. さらに，締付け軸力が大きくなると，スリ ットの影響が表れる. ハイパーロックナットは JIS 標 準ナットに比較して締付け軸力の全帯域において 10 から $20 \mathrm{Nm}$ 程度の高い締付けトルクを有している. (3)ハイパーロックナットのゆるみ止め機能は, 傾斜 座面部の役割が大きく, 締付け軸力が大きくなると, スリット部が変形してねじ山の接触力を増大させる効 果があるものと考えられる.

(4)ハイパーロックナットは締付け軸力が大きくなる と, ボルトに曲げモーメントが発生する. ボルトに発 生する曲げ応力を定式化した.

(5)ハイパーロックナットは締付け軸力が大きくなる と, スリット幅が減少する. スリット幅の隇少はボル ト軸心の変位量を小さくする効果が見受けられた.
スリット幅の減少はナットの構造強度に悪影響を及ぼ すものではない.

さらに, 今後の課題として, ハイパーロックナット を使用したねじ締結体の強度解析および応力評価, 振 動試験によるゆるみ試験, 保証荷重試験, 繰り返し疲 労試験, 而候性試験などによる各種試験を実施し, 工 業的実用性の検証を行うことが必要である. これらに ついては，続報で報告する．

終わりに, 本研究は平成 17 年度経済産業省中小企 業ベンチャー挑戦支援事業(実用化研究開発事業)補助 によるものである．ここに付記し，関係各位に感謝の 意を表する.

\section{文献}

(1)Yoshimoto, L, Points of Design of Jointed Bolt, 2002, pp. 25-26, Japanese Standards Association.

(2)Yamamoto, A., Theory and Calculation of Bolted Joints, 1992, pp. 39-53, Yokendo.

(3)Yamamoto, A, Principle and Design of Bolted Joints, 2004, pp. 30140, Yokendo.

(4)Migita, H., Anti-loosening Nut, Patent, 2005-010412.

(5)Migita, H., Anti-loosening Nut, Patent, 2003-319985, 2004-156637.

(6)Lzumi, S. et al., Three-dimensional Finite Element Analysis on

Tightening and Loosening Mechanism of Bolted Joint,

Transactions of the Japan Society of Mechanical Engineers, Series

C, Vol. 71, No. 702 (2005), pp. 204212.

(7)Izumi, S. et al., Verification of Anti-Loosening Performance of Super Slit Nut by Finite Element Method, Transactions of the Japan Society of Mechanical Engineers, Series C, Vol.71, No. 703(2005), pp. 380-386.

(8)Fukuoka, T., Mechanism and Tightening(1), SCIENCEOF MACHINE, Vol. 54, No. 2(2002), pp. 289-295.

(9)Okada, M. et al., Astudy on Bearing Surface Pressure Distribution of Bolted Joints (Influence of Angular Deviation of Bearing Surface)

Transactions of the Japan Society of Mechanical Engineers, Series C, Vol. 70, No. 699 (2004), pp. 33243330. 